\title{
Once Daily Dose of Nevirapine (400 mg) Versus Twice-Daily Dose (200 mg) of Nevirapine-Based Highly Active Antiretroviral Therapy Regimens in Antiretroviral Naïve Patients with HIV and Tuberculosis Infection in India
}

Sanjeev Sinha ${ }^{1 *}$, Suvrit Jain ${ }^{1}$, Kartik Gupta1, Nawaid Hussain ${ }^{1}$, Sanjay Ranjan', Velpandian T², Kamal Kishore ${ }^{3}$, Padey RM ${ }^{4}$ and BB Rewari ${ }^{5}$

${ }^{1}$ Departments of Medicine, All India Institute of Medical Sciences, New Delhi, India

${ }^{2}$ Ocular Pharmacology and Pharmacy, RPC, All India Institute of Medical Sciences, New Delhi, India

${ }^{3}$ Pharmacology, All India Institute of Medical Sciences, New Delhi, India

${ }^{4}$ Biostatistics, All India Institute of Medical Sciences, New Delhi, India

${ }^{5}$ WHO, New Delhi, India

\begin{abstract}
Nevirapine-based antiretroviral therapy against human immunodeficiency virus (HIV) among Tuberculosis (TB) co-infected individual is complicated as administration of rifampicin along with Nevirapine reduces the plasma concentration of Nevirapine. The objective of the present study is to compare efficacy and safety of Nevirapine 400 $\mathrm{mg}$ once daily (OD) based antiretroviral therapy (ART) with efavirenz based ART and twice daily dose (200 mg) of Nevirapine-based ART regimens in HIV-TB co-infected individuals. ART-naïve HIV-TB patients were randomly assigned to receive either Nevirapine $400 \mathrm{mg}$ OD with zidovudine and lamivudine (Group 1; $n=30$ ), Nevirapine 200 mg BD (Group 2; n=30), efavirenz 600 mg (Group 3, n=31); Nevirapine 400 mg OD with tenofovir (Group 4; n=30) and Nevirapine $400 \mathrm{mg}$ OD without concomitant antitubercular therapy (ATT) (Group 5; n=30). The end points were virological (viral load), immunological (CD4 count) and clinical responses and progression of HIV disease marked by the failure of ART. Our results suggest that Nevirapine $400 \mathrm{mg}$ OD based therapy is as effective as efavirenz-based ART in terms of clinical, immunological and virological response. Our data suggests that Nevirapine $400 \mathrm{mg}$ OD group had favorable treatment outcome as compared to Nevirapine $200 \mathrm{mg} 1 \mathrm{BD}$ group.
\end{abstract}

We conclude that Nevirapine $400 \mathrm{mg}$ OD based ART combined with tenofovir and lamivudine could be an effective alternative to improve compliance in the resource-limited settings in patients with HIV-TB co-infection. Further large multicentric study with bigger sample size will be required to confirm these findings.

Keywords: Nevirapine 400 mg; HIV-TB co-infection; CD4 count; Viral load; ART; ATT

\section{Introduction}

Of the total 36.7 million people living with HIV (PLHIV) in 2015, 1.2 million got infected with tuberculosis (TB). Approximately onethird of all deaths among PLHIV ( $\sim 0.39$ million) in 2015 were because of TB. While PLHIV have more chances of harboring drug-resistant pathogens, and ART is crucial for strengthened immune response, only around $78 \%$ of those with TB coinfection were started on ART [1]. HIV accounted for $25 \%$ of all TB-related deaths in 2014 [2].

Treatment of HIV-TB co-infection continues to be a great challenge. The extensive drug burden, drug interactions, side effects and toxicities; need for frequent biochemical monitoring and dealing with associated co-morbidities are some of the important pitfalls. For HIV-TB coinfected patients, the World Health Organization (WHO) and National AIDS Control Organization (NACO) recommends efavirenz-based ART, as rifampicin, an essential component of ATT reduces the plasma concentration of Nevirapine [3,4]. However, Nevirapine has been frequently used in India in HIV/AIDS patients as a component of firstline regimens along with Nucleoside Reverse Transcriptase Inhibitors (NRTIs) (zidovudine and lamivudine). Multiple trials have proven that Nevirapine-based HAART produces comparable clinical, virological and immunological responses in patients who are co-infected with HIV and TB $[5,6]$.

Drug adherence is an important determinant of treatment outcomes; good adherence is a pre-requisite for optimal virological control. In order to simplify treatment regimens and ensure optimal adherence, the combination of a single daily dose of extended-release Nevirapine 400 $\mathrm{mg}$ in combination with other NRTIs (tenofovir, lamivudine) is being evaluated as an attractive option. Although Efavirenz is also available as a single daily dose, Nevirapine $400 \mathrm{mg}$ OD may be considered in some cases for e.g. neurotoxicity. Nevirapine $400 \mathrm{mg}$ OD has been previously compared with Nevirapine $200 \mathrm{mg}$ BD in HIV-infected individuals with conflicting but encouraging results in different trials [7,8]. It has shown good clinical efficacy despite some concerns of increased liver toxicity but very few studies have directly compared Nevirapine $400 \mathrm{mg}$ OD and efavirenz in HIV-TB co-infected cohort [9] the present study is unique in the sense that Nevirapine $400 \mathrm{mg}$ OD has been directly compared to Efavirenz $600 \mathrm{mg}$ OD based ART regimens in HIV-TB co-infected patients. Plasma Nevirapine concentrations were measured in the test arms (HIV-TB co-infected) with the control arm (Nevirapine $400 \mathrm{mg}$ OD in HIV patients without TB) and pharmacokinetic parameters were correlated with clinical efficacy.

${ }^{*}$ Corresponding author: Dr. Sanjeev Sinha, Professor, Department of Medicine All India Institute of Medical Sciences, Ansari Nagar, New Delhi 110029, India, Tel: 91-9810164416; Fax: 011-26588866; E-mail: drsanjeevsinha@gmail.com

Received March 26, 2017; Accepted April 19, 2017; Published April 26, 2017

Citation: Sinha S, Jain S, Gupta K, Hussain N, Ranjan S, et al. (2017) Once Daily Dose of Nevirapine $(400 \mathrm{mg})$ Versus Twice-Daily Dose $(200 \mathrm{mg})$ of NevirapineBased Highly Active Antiretroviral Therapy Regimens in Antiretroviral Naïve Patients with HIV and Tuberculosis Infection in India. J AIDS Clin Res 8: 689. doi: 10.4172/2155-6113.1000689

Copyright: (C) 2017 Sinha S, et al. This is an open-access article distributed under the terms of the Creative Commons Attribution License, which permits unrestricted use, distribution, and reproduction in any medium, provided the original author and source are credited. 
Citation: Sinha S, Jain S, Gupta K, Hussain N, Ranjan S, et al. (2017) Once Daily Dose of Nevirapine (400 mg) Versus Twice-Daily Dose (200 mg) of Nevirapine-Based Highly Active Antiretroviral Therapy Regimens in Antiretroviral Naïve Patients with HIV and Tuberculosis Infection in India. J AIDS Clin Res 8: 689. doi: 10.4172/2155-6113.1000689

Page 2 of 7

\section{Methods}

The present study was an open-label, randomized, case-control study conducted at the All India Institute of Medical Sciences (AIIMS), New Delhi from September 2012 to November 2015. HIV-positive ART-naïve patients with concomitant TB were enrolled as study participants. Patients with abnormal renal and hepatic function, hepatitis $\mathrm{B}$ or $\mathrm{C}$, age $<18$ years, diabetes mellitus, on antiepileptic drugs, immunosuppressant and other drugs that induce hepatic microsomal enzyme systems were excluded. All female patients were screened for urinary $\beta$-HCG for pregnancy and were excluded if tested positive for pregnancy. HIV infection was documented by licensed ELISA test kit (as per NACO guidelines) [10]. CD4/CD8 cell counts were determined by flow cytometry (BD FACS CALIBUR).Viral load testing was done using Abbott's Real Time HIV-1 Quantitative Assay performed on Abbott's automated high throughput m2000 system. The protocol was approved by the institutional research ethics committee of the AIIMS, New Delhi. Written informed consent was obtained from all study subjects enrolled in the trial. Block randomization with variable block size was used as a method of randomization to generate random numbers for allocation of patients into one of the 5 study groups. Codes were kept in an opaque envelope arranged serially which was opened after the patient was found eligible for enrolment. This envelope was kept with a person not involved in the study.

\section{Initial evaluation}

All patients had a thorough general and systemic physical examination including laboratory workup that consisted of complete blood counts, erythrocyte sedimentation rate (ESR), fasting blood glucose (FBS), renal function tests (RFT), liver function tests (LFT), urine for microscopic examinations, CD4 counts and plasma HIV viral load.

\section{Treatment}

In this randomised open label trial, eligible ART-naïve HIV-TB patients were randomised to four different ART study arms along with rifampicin-based ATT; Nevirapine $400 \mathrm{mg}$ OD with zidovudine and lamivudine (Group1); Nevirapine $200 \mathrm{mg}$ BD with zidovudine and lamivudine (Group 2); efavirenz with zidovudine and lamivudine (Group 3) and Nevirapine $400 \mathrm{mg}$ OD with tenofovir with lamivudine (Group 4). A fifth arm consisted of HIV patients on zidovudine with lamivudine and Nevirapine $400 \mathrm{mg}$ OD without concomitant ATT. We have used the drugs available for the national program available at ART clinic at All India Institute of Medical Sciences except NPV $400 \mathrm{mg}$ which was prepared at National Institute of Pharmaceutical Education and Research, Ahmedabad, India on the permission of NACO and Department of Pharmaceuticals, Government of India. All the ARTnaïve patients attending the ART clinic at our center were screened for TB by physical examination, sputum examination for acid-fast bacilli (AFB), chest radiographs and ultrasound abdomen as part of routine screening recommended by NACO and Revised National Tuberculosis Control Programme (RNTCP) [10]. ART-naïve patients co-infected with TB were randomized into one of the trial arms using computer generated random number tables. ATT was started according to the RNTCP guidelines for directly observed therapy short course chemotherapy (DOTS). After two weeks of ATT, respective ART regimens were started as per randomization which was done at the time of diagnosis of TB. Zidovudine was given in a dose of $300 \mathrm{mg}$ $\mathrm{BD}$, lamivudine $150 \mathrm{mg} \mathrm{BD}$; efavirenz $600 \mathrm{mg}$ OD; Nevirapine in two dosages $200 \mathrm{mg} \mathrm{BD}$ and $400 \mathrm{mg}$ extended release tablet OD.

\section{Follow-up}

After the start of ART, patients were assessed at 2, 4 and 6 weeks followed by every 4 weeks till a follow-up of 48 weeks was completed. A complete hemogram, LFT, RFT tests were obtained on all the visits. CD4 counts were obtained at baseline, 12, 24, 36 and 48 weeks and HIV plasma viral loads were measured at baseline, 24 and 48 weeks after the start of ART. Trough Nevirapine concentrations were assessed at 2, 4, 6 and 26 weeks, $12 \mathrm{~h}$ after the evening dose of Nevirapine in all patients. The method used for the measurement of Nevirapine concentrations has been described earlier [11].

\section{Definitions}

Disease progression or clinical failure was defined as a new or recurrent WHO stage 4 condition, after at least 24 weeks of ART. Immunological failure was defined as a decrease in $\mathrm{CD} 4$ count from the baseline values, for that either $50 \%$ decrease from the peak CD4 count during the treatment or persistent counts below $100 \mathrm{cells} / \mathrm{mm}^{3}$ after 24 weeks of ART. Virological failure was defined as failure to suppress viral load to $<400$ copies/ml at the end of $24^{\text {th }}$ week of ART or to sustain this level of suppression till $48^{\text {th }}$ week of treatment. The composite unfavorable outcome was defined as a virological, immunological or clinical failure at any time or death due to any cause during the treatment. Combined ART failure was defined as the development of clinical, immunological or virological failure at any time during the treatment. Treatment success and failure of ATT were defined as per the WHO guidelines [12].

\section{Outcomes}

The primary outcome of the study was the proportion of the subjects after 48 weeks who died or had a CD4 count below 200 cells/ $\mathrm{ml}$ at 24 weeks. Two different time points to evaluate primary outcome were chosen in order to account for ART-ATT interaction, especially in groups receiving Nevirapine during 24 weeks of ATT. The secondary outcome of the study was an assessment of safety and tolerability of ART, measured by the proportion of the subjects with toxicities and the proportion of subjects changed/discontinued ART because of toxicities or treatment failure. The overall outcome of ATT was assessed by both the outcomes.

\section{Statistical analysis}

Anticipated rate of unfavorable outcome in standard arm (Efavirenz group) and test group (Nevirapine $400 \mathrm{mg}$ OD) was $10 \%$ and $15 \%$, respectively, this required 34 patients in each group to show non-inferiority of the Nevirapine $400 \mathrm{mg}$ OD group (Non-inferiority margin being considered as $15 \%$, with $95 \%$ confidence and $80 \%$ power). 30 patients in each group were enrolled due to paucity of time. Data was analysed according to the Intention to treat analysis (ITT) principle. All continuous variables having normal distribution were analyzed using Student's t-test. Ordinal variables and variables with non-normal distribution were analyzed using Wilcoxon rank-sum test. The categorical variables with dichotomous outcomes like ART failure and unfavorable outcomes were analyzed using logistic regression model. Generalized estimation equations (GEE) were used to analyze the predictors of immunological response in terms of the increase in CD4 count. Statistical analyses were performed using software package STATA version 12.0 [(intercooled version), Stata Corporation, Houston, Texas, USA].

\section{Results}

Among the total 121 HIV-TB co-infected patients enrolled, 30 were randomized into Nevirapine $400 \mathrm{mg}$ OD (with zidovudine and lamivudine) arm, 30 into Nevirapine $200 \mathrm{mg}$ BD arm, 31 into 
Citation: Sinha S, Jain S, Gupta K, Hussain N, Ranjan S, et al. (2017) Once Daily Dose of Nevirapine (400 mg) Versus Twice-Daily Dose (200 mg) of Nevirapine-Based Highly Active Antiretroviral Therapy Regimens in Antiretroviral Naïve Patients with HIV and Tuberculosis Infection in India. J AIDS Clin Res 8: 689. doi: 10.4172/2155-6113.1000689

Page 3 of 7

efavirenz arm, 30 into Nevirapine $400 \mathrm{mg}$ OD (with tenofovir and lamivudine) arm (Figure 1). A total of 30 ART -naïve HIV- infected patients without concomitant TB co-infection were also included who received Nevirapine $400 \mathrm{mg}$ OD in the absence of ATT. Their baseline characteristics are summarized in Table 1. Mean CD4 count was significantly higher in group 1 than in other groups. Serum albumin level, a marker of liver synthetic function and ALT were more favorable in Nevirapine $400 \mathrm{mg}$ group as compared to efavirenz group. Rest of

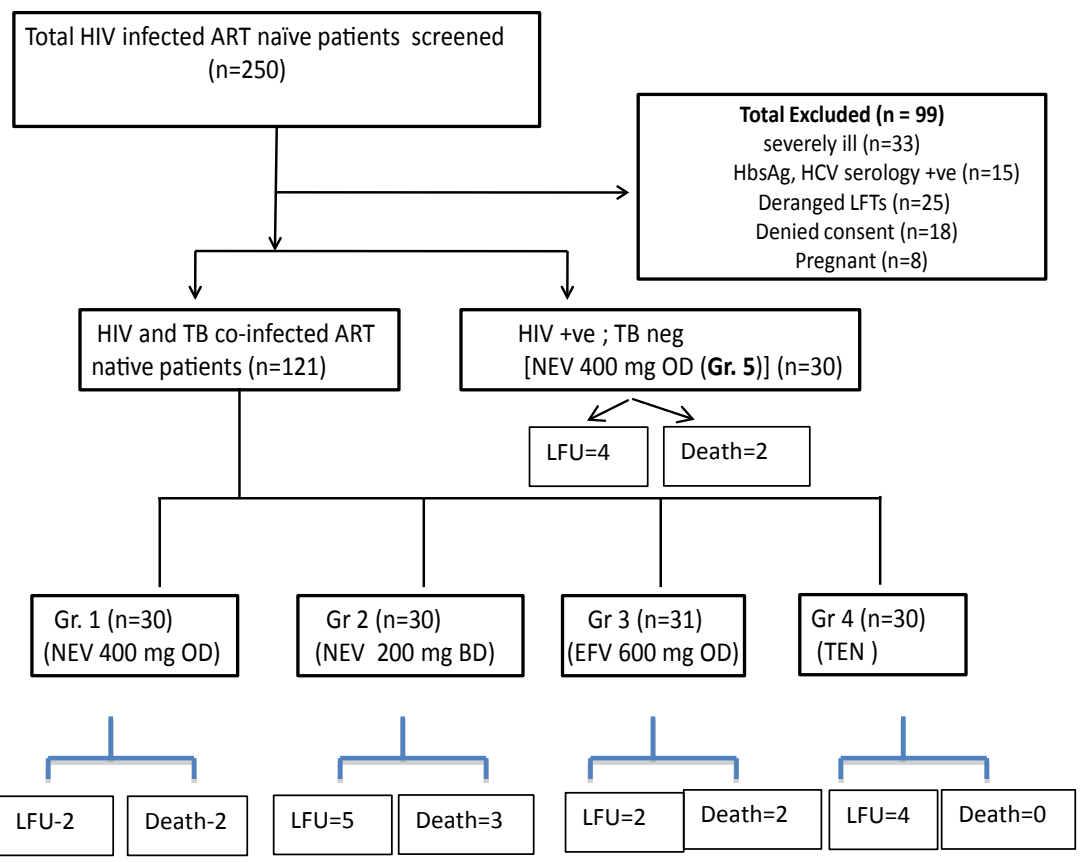

LFU: Lost to Follow Up, Group 1: Nevirapine 400 mg, Group 2: Nevirapine 200 mg, Group 3: Efavirenz, Group 4: Tenofovir, Group 5: Control

Figure 1: Profile of the patients in the study (consort).

\begin{tabular}{|c|c|c|c|c|c|c|}
\hline Variables & $\begin{array}{c}\text { Group } 1 \\
n=30 \\
\text { (mean } \pm S D)\end{array}$ & $\begin{array}{c}\text { Group 2 } \\
n=30 \\
\text { (mean } \pm \text { SD) }\end{array}$ & $\begin{array}{c}\text { Group } 3 \\
n=31 \\
(\text { mean } \pm S D)\end{array}$ & $\begin{array}{c}\text { Group } 4 \\
n=30 \\
\text { (mean } \pm S D)\end{array}$ & $\begin{array}{c}\text { Group } 5 \\
n=30 \\
(m e a n \pm S D)\end{array}$ & $P$ value \\
\hline Age & $35.7 \pm 9.83$ & $36.9 \pm 7.94$ & $35.83 \pm 7.68$ & $33.93 \pm 7.54$ & $36.16 \pm 8.85$ & 0.163 \\
\hline $\begin{array}{l}\text { Sex (\%) } \\
\text { Male } \\
\text { Female }\end{array}$ & $\begin{array}{c}27(90) \\
3(10)\end{array}$ & $\begin{array}{c}24(77) \\
7(23)\end{array}$ & $\begin{array}{c}25(80) \\
6(20)\end{array}$ & $\begin{array}{c}21(70) \\
9(30)\end{array}$ & $\begin{array}{l}20(65) \\
11(35)\end{array}$ & 0.719 \\
\hline Weight (kg) & $54 \pm 6.2$ & $58 \pm 11.1$ & $54 \pm 7.75$ & $53.4 \pm 5.76$ & $55.54 \pm 10.1$ & 0.27 \\
\hline $\mathrm{Hb}(\mathrm{gm} / \mathrm{dl})$ & $11.96 \pm 1.37$ & $11.29 \pm 1.97$ & $10.42 \pm 1.65$ & $9.63 \pm 1.60$ & $11.31 \pm 1.38$ & 0.001 \\
\hline Platelets*1000/uL & $\begin{array}{c}203 \\
(10-521)\end{array}$ & $\begin{array}{c}246 \\
(188-650)\end{array}$ & $\begin{array}{c}185 \\
(65-316)\end{array}$ & $\begin{array}{c}235 \\
(80-480)\end{array}$ & $\begin{array}{c}184 \\
(72-380)\end{array}$ & 0.23 \\
\hline TLC /ul & $5627 \pm 1452$ & $5583.54 \pm 1995.9$ & $5490 \pm 2088.59$ & $6861 \pm 4047$ & $6172 \pm 1836$ & 0.127 \\
\hline Urea (mg\%) & $23.27 \pm 9.14$ & $20.93 \pm 5.57$ & $23.25 \pm 9.09$ & $24.03 \pm 7.16$ & $23.12 \pm 6.72$ & 0.58 \\
\hline Creatinine (mg\%) & $0.76 \pm 0.23$ & $0.7612 \pm 0.233$ & $0.77 \pm 0.22$ & $0.81 \pm 0.30$ & $0.77 \pm 0.28$ & 0.94 \\
\hline Bilirubin* $\left.^{*} \mathbf{m g} \%\right)$ & $\begin{array}{c}0.5 \\
(0.1-0.9)\end{array}$ & $\begin{array}{c}0.5 \\
(0.1-1.6)\end{array}$ & $\begin{array}{c}0.6 \\
(0.4-1)\end{array}$ & $\begin{array}{c}0.5 \\
(0.1-1)\end{array}$ & $\begin{array}{c}0.6 \\
(0.3-13)\end{array}$ & 0.0214 \\
\hline Albumin* (gm/dl) & $\begin{array}{c}4.15 \\
(2.01-5)\end{array}$ & $\begin{array}{c}4 \\
(2.5-5.3)\end{array}$ & $\begin{array}{c}3.6 \\
(1.9-5)\end{array}$ & $\begin{array}{c}3.5 \\
(0-4.3)\end{array}$ & $\begin{array}{c}3.9 \\
(2-5.2)\end{array}$ & 0.0034 \\
\hline SGOT* $^{*}$ (IU/L) & $\begin{array}{c}27.5 \\
(16-83)\end{array}$ & $\begin{array}{c}33 \\
(14-69)\end{array}$ & $\begin{array}{c}34 \\
(20-111)\end{array}$ & $\begin{array}{c}32 \\
(16-99)\end{array}$ & $\begin{array}{c}49 \\
(16-85)\end{array}$ & 0.0228 \\
\hline SGPT* (IU/L) & $\begin{array}{c}24 \\
(11-90)\end{array}$ & $\begin{array}{c}29 \\
(13-90)\end{array}$ & $\begin{array}{c}33 \\
(12-70)\end{array}$ & $\begin{array}{c}29.5 \\
(17-85)\end{array}$ & $\begin{array}{c}26 \\
(14-91)\end{array}$ & 0.154 \\
\hline ALP* $^{*}(\mathrm{IU} / \mathrm{L})$ & $\begin{array}{c}194.5 \\
(48.4-497)\end{array}$ & $\begin{array}{c}249 \\
(112-1934)\end{array}$ & $\begin{array}{c}340 \\
(54-2430)\end{array}$ & $\begin{array}{c}210 \\
(72-737)\end{array}$ & $\begin{array}{c}183 \\
(91-325)\end{array}$ & 0.001 \\
\hline CD4 (cells/ul) & $273.3 \pm 175$ & $191 \pm 139$ & $183 \pm 169$ & $171 \pm 109$ & $239 \pm 95$ & 0.0063 \\
\hline $\log _{10}$ Viral load (copy/ml) & $5.2 \pm 0.7$ & $5.41 \pm 0.78$ & $5.10 \pm 0.9$ & $5.34 \pm 0.68$ & $4.98 \pm 0.73$ & 0.1719 \\
\hline
\end{tabular}

* Values have been represented in Mean \pm SD, Median range and Frequency (\%)

Group 1: Nevirapine 400 mg, Group 2: Nevirapine200 mg, Group 3: Efavirenz, Group 4: Tenofovir, Group 5: Control, SGOT: Serum Glutamic Oxaloacetic Transaminase, SGPT: Serum Glutamic Pyruvic Transaminase, IU: International Unit, ALP: Alkaline Phosphatase

Table 1: Baseline characteristics of the study population. 
Citation: Sinha S, Jain S, Gupta K, Hussain N, Ranjan S, et al. (2017) Once Daily Dose of Nevirapine (400 mg) Versus Twice-Daily Dose (200 mg) of Nevirapine-Based Highly Active Antiretroviral Therapy Regimens in Antiretroviral Naïve Patients with HIV and Tuberculosis Infection in India. J AIDS Clin Res 8: 689. doi: 10.4172/2155-6113.1000689

Page 4 of 7

the parameters were comparable between all the groups. Males were predominant among the study subjects with an average age (30-40 years). A significant proportion of patients $(\sim 60 \%)$ in the different study arms had extrapulmonary TB which was more common; however, between-group difference was not significant. Lymph node TB followed by abdominal TB were the most common sites of extrapulmonary involvement. By virtue of having extrapulmonary $\mathrm{TB}$, most of the patients in study arms were in WHO stage 4 of AIDS. Most of the patients in the different study arms received category I DOTS, which is thrice weekly therapy.

First, we were interested to compare the treatment outcome between the Nevirapine $400 \mathrm{mg}$ OD [with zidovudine and lamivudine] (Group 1) and Efavirenz group (Group 3) as this was one of the main objectives of the study. With treatment patients in both, the groups had an increase in the hemoglobin $(\mathrm{Hb})$ and albumin, which can be considered surrogate markers for nutritional improvement. In Group 1 hemoglobin and albumin increased from $11.96 \pm 1.6 \mathrm{gm} / \mathrm{dL}$ to $11.99 \pm 0.60 \mathrm{gm} / \mathrm{dL}$ and $3.9 \pm 0.56 \mathrm{gm} / \mathrm{dL}$ to $4.10 \pm 0.70 \mathrm{mg} \%$, respectively whereas in Group 3 from $10.40 \pm 1.6$ to $12.0 \pm 0.90 \mathrm{gm} / \mathrm{dL}$ and $3.6 \pm 0.8$ to $3.8 \pm 0.50 \mathrm{mg} \%$, respectively (Table 1, Table 2). After 48 weeks both Group 1 and Group 3 showed an increase in the mean CD4 count with Nevirapine $400 \mathrm{mg}$ OD showing an increase from baseline of $273.3 \mathrm{cells} / \mu \mathrm{l}$ to $456 \mathrm{cells} / \mu \mathrm{l}$, whereas in efavirenz group CD4 increased from 183 cells/ $\mu$ lo 347 cells/ $\mu$ l (Tables 1 and 2 and Figure 2). Both groups had comparable low mortality rate (2 in each group). We did not observe any case of virological failure in both efavirenz and Nevirapine $400 \mathrm{mg}$ OD group after 48 weeks of treatment (Figure 3). Overall, our data suggests that Nevirapine $400 \mathrm{mg}$ OD group had a comparable composite unfavorable outcome as compared to EFV group (Tables 1 and 2 and Figure 2).

Similarly, we compared the treatment outcome between group 1 and group 4 (Tables 1 and 2 and Figure 2). the increase in mean CD 4 counts in group 4 from baseline to 24 weeks and 48 weeks post-treatment was 144cells/ $\mu \mathrm{l}$ and 194 cells/ $\mu \mathrm{l}$ and that of group 1 was 117 cells/ $\mu \mathrm{l}$ and 184 cells/ $\mu$ l, respectively This data suggests that immunological outcome in both the groups are similar. The majority of the samples from both the groups had a viral load $<400$ copies/ml after 96 weeks of treatment. In tenofovir group, however, there were 3 individuals (10\%) with viral load $>400$ copies $/ \mathrm{ml}$ after 48 weeks post-treatment (Figure 4 ).

Another aim of our study was to compare Group 1 with Group 2.

\begin{tabular}{|c|c|c|c|c|c|c|}
\hline Variable & $\begin{array}{c}\text { Group } 1 \\
n=30 \\
\text { (Mean } \pm \text { SD) }\end{array}$ & $\begin{array}{c}\text { Group } 2 \\
n=30 \\
\text { (Mean } \pm \text { SD) }\end{array}$ & $\begin{array}{c}\text { Group } 3 \\
n=31 \\
\text { (Mean } \pm S D)\end{array}$ & $\begin{array}{c}\text { Group } 4 \\
n=30 \\
\text { (Mean } \pm \text { SD) }\end{array}$ & $\begin{array}{c}\text { Group } 5 \\
n=30 \\
\text { (Mean } \pm \text { SD) }\end{array}$ & $P$ value \\
\hline $\begin{array}{l}\text { Weight }(\mathrm{kg}) \\
24 \text { weeks } \\
96 \text { weeks }\end{array}$ & $\begin{array}{c}55.95 \pm 6.49 \\
60.57 \pm 5.8\end{array}$ & $\begin{array}{l}60 \pm 11.04 \\
64.4 \pm 10.5\end{array}$ & $\begin{array}{c}57.2 \pm 6.77 \\
60.5 \pm 7.5\end{array}$ & $\begin{array}{c}58.57 \pm 4.69 \\
60.6 \pm 3.8\end{array}$ & $\begin{array}{c}58.58 \pm 10.07 \\
60.6 \pm 9.8\end{array}$ & $\begin{array}{l}0.366 \\
0.455\end{array}$ \\
\hline $\begin{array}{l}\mathrm{Hb}(\mathrm{gm} / \mathrm{dL}) \\
24 \text { weeks } \\
96 \text { weeks }\end{array}$ & $\begin{array}{l}11.99 \pm 1.33 \\
12.13 \pm 0.58\end{array}$ & $\begin{array}{l}11.89 \pm 1.39 \\
12.37 \pm 0.88\end{array}$ & $\begin{array}{c}12.05 \pm 0.9 \\
12.07 \pm 0.95\end{array}$ & $\begin{array}{l}12.40 \pm 0.81 \\
12.02 \pm 0.68\end{array}$ & $\begin{array}{l}11.52 \pm 0.84 \\
11.87 \pm 0.53\end{array}$ & $\begin{array}{c}0.06 \\
0.3281\end{array}$ \\
\hline $\begin{array}{l}\text { Platelets }\left({ }^{*} 1000 / u L\right) \\
24 \text { weeks* } \\
96 \text { weeks }^{*}\end{array}$ & $\begin{array}{c}235(3-380) \\
234(175-355)\end{array}$ & $\begin{array}{l}220(120-5600) \\
237(121-280)\end{array}$ & $\begin{array}{l}236(112-320) \\
220(102-304)\end{array}$ & $\begin{array}{c}255.5(150-298) \\
233(140-289)\end{array}$ & $\begin{array}{l}245(122-319) \\
245(132-265)\end{array}$ & $\begin{array}{c}0.05 \\
0.5465\end{array}$ \\
\hline $\begin{array}{l}\frac{T L C(u L)}{24 \text { weeks* }} \\
96 \text { weeks }\end{array}$ & $\begin{array}{c}6500(3600-8100) \\
7268 \pm 1176\end{array}$ & $\begin{array}{c}6500(150-7800) \\
6615 \pm 1129\end{array}$ & $\begin{array}{c}7200(3800-9000) \\
6955 \pm 1303\end{array}$ & $\begin{array}{c}6300(3700-6900) \\
6813 \pm 432\end{array}$ & $\begin{array}{c}6700(4500-8000) \\
6082 \pm 788\end{array}$ & $\begin{array}{c}0.03 \\
0.0053\end{array}$ \\
\hline $\begin{array}{l}\text { Urea }(\mathrm{mg} \%) \\
24 \text { weeks } \\
96 \text { weeks }\end{array}$ & $\begin{array}{c}24.25 \pm 5.88 \\
25 \pm 3.5\end{array}$ & $\begin{array}{l}19.5 \pm 6.75 \\
23.57 \pm 6.6\end{array}$ & $\begin{array}{l}25.26 \pm 5.6 \\
22.77 \pm 6.7\end{array}$ & $\begin{array}{c}26 \pm 3.5 \\
23.47 \pm 4.78\end{array}$ & $\begin{array}{c}26.87 \pm 4.61 \\
24.86 \pm 3.73\end{array}$ & $\begin{array}{c}0.001 \\
0.5965\end{array}$ \\
\hline $\begin{array}{l}\text { Creatinine }(\mathrm{mg} \%) \\
24 \text { weeks } \\
96 \text { weeks }\end{array}$ & $\begin{array}{c}0.8 \pm 0.26 \\
0.525 \pm 0.19\end{array}$ & $\begin{array}{c}0.67 \pm 0.22 \\
0.65 \pm 0.2\end{array}$ & $\begin{array}{l}0.72 \pm 0.21 \\
0.67 \pm 0.21\end{array}$ & $\begin{array}{l}0.55 \pm 0.20 \\
0.63 \pm 0.17\end{array}$ & $\begin{array}{c}0.7 \pm 0.23 \\
0.66 \pm 0.28\end{array}$ & $\begin{array}{c}0.004 \\
0.2671\end{array}$ \\
\hline $\begin{array}{l}\text { Bilirubin }(\mathrm{mg} \%) \\
24 \text { weeks } \\
96 \text { weeks }\end{array}$ & $\begin{array}{l}0.58 \pm 0.20 \\
0.66 \pm 0.22\end{array}$ & $\begin{array}{l}1.36 \pm 2.36 \\
0.63 \pm 0.15\end{array}$ & $\begin{array}{c}0.8 \pm 1.17 \\
0.61 \pm 0.13\end{array}$ & $\begin{array}{l}0.51 \pm 0.18 \\
0.51 \pm 0.11\end{array}$ & $\begin{array}{l}0.68 \pm 0.19 \\
0.55 \pm 0.22\end{array}$ & $\begin{array}{c}0.023 \\
0.0595\end{array}$ \\
\hline $\begin{array}{l}\text { Albumin (gm/dL) } \\
24 \text { weeks* } \\
96 \text { weeks* }\end{array}$ & $\begin{array}{l}4(2.9-5.2) \\
4(2.9-5.9)\end{array}$ & $\begin{array}{c}4.2(2.9-4.6) \\
4.2(3-5.2)\end{array}$ & $\begin{array}{l}3.9(2.7-4.7) \\
4.2(3.1-6.2)\end{array}$ & $\begin{array}{c}3.6(3.2-4.2) \\
4(2.8-5.2)\end{array}$ & $\begin{array}{c}3.55(3.1-4.9) \\
3.6(2.8-4.8)\end{array}$ & $\begin{array}{l}0.006 \\
0.231\end{array}$ \\
\hline $\begin{array}{l}\text { SGOT }(\mathrm{IU} / \mathrm{L}) \\
24 \text { weeks* } \\
96 \text { weeks* }\end{array}$ & $\begin{array}{l}26.5(15-50) \\
29(20-46)\end{array}$ & $\begin{array}{c}26(4-53) \\
31(19-120)\end{array}$ & $\begin{array}{l}29(15-69) \\
27(17-46)\end{array}$ & $\begin{array}{l}28(24-50) \\
27(12-85)\end{array}$ & $\begin{array}{l}26.5(17-42) \\
25(20-45)\end{array}$ & $\begin{array}{l}0.3924 \\
0.1966\end{array}$ \\
\hline $\begin{array}{l}\text { SGPT }(\mathrm{IU} / \mathrm{L}) \\
24 \text { weeks* } \\
96 \text { weeks* }\end{array}$ & $\begin{array}{c}31.5(11-49.3) \\
28(20-32)\end{array}$ & $\begin{array}{l}25.5(18-52) \\
26(17-100)\end{array}$ & $\begin{array}{c}26.5(17-71) \\
27(17-63)\end{array}$ & $\begin{array}{l}27(22-32) \\
29(17-76)\end{array}$ & $\begin{array}{l}29(17-44) \\
26(21-38)\end{array}$ & $\begin{array}{c}0.597 \\
0.7433\end{array}$ \\
\hline $\begin{array}{l}\frac{A L P(I U / L)}{24 \text { weeks* }} \\
96 \text { weeks* }\end{array}$ & $\begin{array}{c}228(27-345) \\
220(118-315)\end{array}$ & $\begin{array}{c}225.5(22-2451) \\
256(210-419)\end{array}$ & $\begin{array}{c}260.5(172-519) \\
224(82-355)\end{array}$ & $\begin{array}{l}278(145-326) \\
217(125-305)\end{array}$ & $\begin{array}{l}230(134-365) \\
230(210-289)\end{array}$ & $\begin{array}{c}0.0049 \\
0.690\end{array}$ \\
\hline $\begin{array}{l}\text { CD4 (cells/ul) } \\
24 \text { weeks } \\
96 \text { weeks }\end{array}$ & $\begin{aligned} 390.3 & \pm 173.5 \\
456 & \pm 179\end{aligned}$ & $\begin{array}{c}278.6 \pm 109 \\
345 \pm 136\end{array}$ & $\begin{array}{c}305.86 \pm 165 \\
347 \pm 155\end{array}$ & $\begin{array}{c}315.39 \pm 129 \\
363 \pm 147\end{array}$ & $\begin{array}{c}305.7 \pm 134 \\
407 \pm 136\end{array}$ & $\begin{array}{c}0.283 \\
0.1733\end{array}$ \\
\hline $\begin{array}{l}\log _{10} \text { Viral load (copy/ml) } \\
24 \text { weeks } \\
96 \text { weeks }\end{array}$ & $\begin{array}{c}1.77 \pm 0.51 \\
1.61 \pm 0.244\end{array}$ & $\begin{array}{l}1.99 \pm 0.89 \\
1.76 \pm 0.66\end{array}$ & $\begin{array}{c}1.66 \pm 0.16 \\
1.61 \pm 0.043\end{array}$ & $\begin{array}{l}2.02 \pm 1.09 \\
2.11 \pm 1.21\end{array}$ & $\begin{array}{l}1.81 \pm 0.89 \\
1.65 \pm 0.22\end{array}$ & $\begin{array}{l}0.428 \\
0.067\end{array}$ \\
\hline
\end{tabular}

Median values (ranges) are presented

Group 1: Nevirapine 400 mg, Group 2: Nevirapine 200 mg, Group 3: Efavirenz, Group 4: Tenofovir, Group 5: Control, SGOT: Serum Glutamic Oxaloacetic Transaminase, SGPT: Serum Glutamic Pyruvic Transaminase, IU: International Unit, ALP: Alkaline Phosphatase

Table 2: Follow up data of study groups at 12 months. 
Citation: Sinha S, Jain S, Gupta K, Hussain N, Ranjan S, et al. (2017) Once Daily Dose of Nevirapine (400 mg) Versus Twice-Daily Dose (200 mg) of Nevirapine-Based Highly Active Antiretroviral Therapy Regimens in Antiretroviral Naïve Patients with HIV and Tuberculosis Infection in India. J AIDS Clin Res 8: 689. doi: 10.4172/2155-6113.1000689

Page 5 of 7

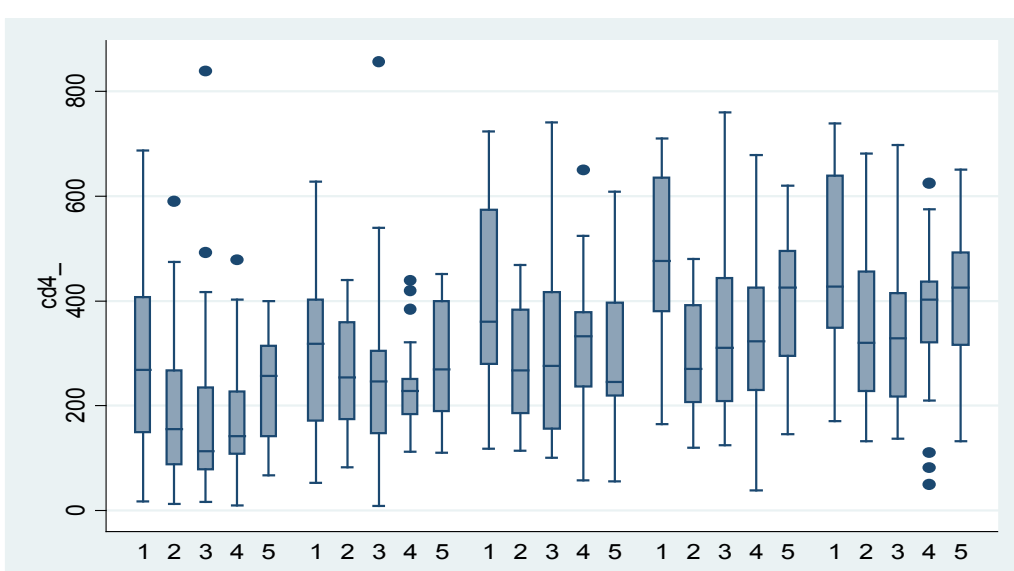

Group 1: Nevirapine 400mg OD with zidovudine and lamivudine, Group 2: Nevirapine 200 mg BD, Group 3: Efavirenz 600 mg OD, Group 4: Nevirapine 400mg OD with Tenofovir, Group 5: Nevirapine $400 \mathrm{mg}$ OD without ATT

Figure 2: Box plot showing CD4 values for study groups at different time points.

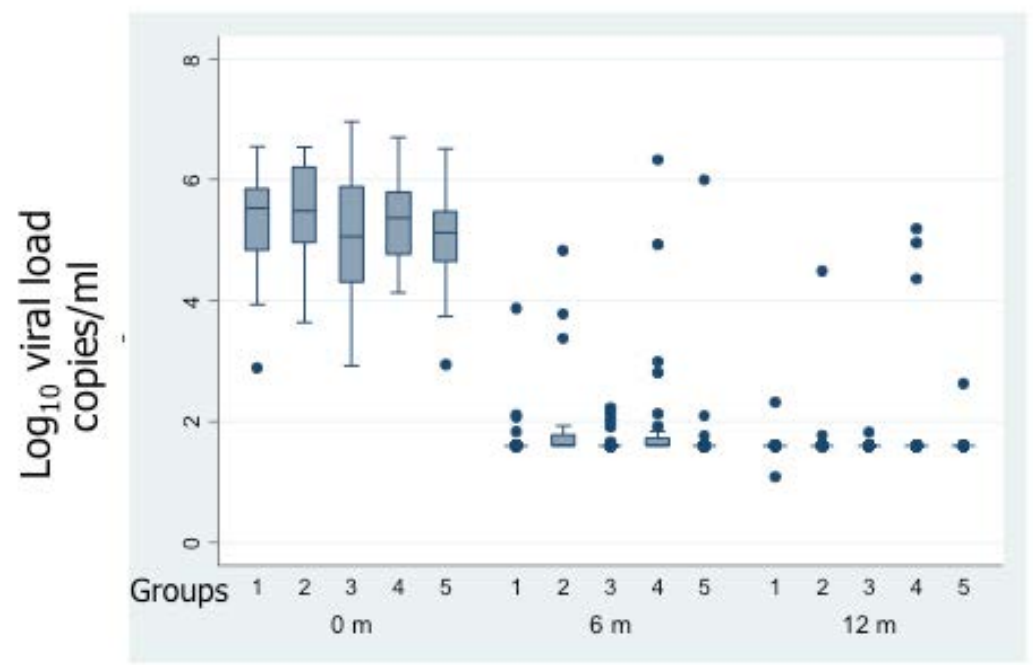

Days post-treatment

Group 1: Nevirapine 400mg OD with zidovudine and lamivudine, Group 2: Nevirapine 200 mg BD, Group 3: Efavirenz 600 mg OD, Group 4: Nevirapine 400mg OD with Tenofovir, Group 5: Nevirapine $400 \mathrm{mg}$ OD without ATT

Figure 3: Box plot showing log viral load values for study groups at different time points.

Our data suggests that group 1 had a better outcome as observed from the immunological and virological response. The increase in mean CD4 counts in group 1 was 117 cells $/ \mu \mathrm{l}$ and 184 cells/ $\mu$ l, respectively after 24 and 48 weeks of post-treatment whereas that in the case of group 2 are $87 \mathrm{cells} / \mu \mathrm{l}$ and $150 \mathrm{cells} / \mu \mathrm{l}$, respectively (Tables 1 and 2 and Figure $2)$. The mean $\log$ viral loads were $1.77( \pm 0.51)$ and $1.61( \pm 0.24)$ at 24 weeks and 48 weeks post-treatment among group one and that in group 2 are $1.99( \pm 0.89)$ and $1.76( \pm 0.66)$, respectively. Moreover, there were 3 and 1 individuals who had viral copy number $>400$ copies $/ \mathrm{mL} 24$ and 48 weeks post-treatment respectively in group 2 whereas group 1 had none at both the time points.

The mean Nevirapine level in the different study arms at all-time points except 2 weeks was above $2.2 \mu \mathrm{g} / \mathrm{ml}$ and no difference with clinical outcome was observed. The Nevirapine levels in the study arms I, II and IV was comparable and statistically insignificant to the control arm (group V) (mean level above $2.3 \mu \mathrm{g} / \mathrm{ml}$ ), at all times. This result suggests that ATT does not have significant interactions which may implicate adverse clinical outcome with Nevirapine-based treatment.

Drug-induced hepatotoxicity occurred in a total of seven patients; one patient in Nevirapine $400 \mathrm{mg}$ OD regimen and rest in other groups. Most events were likely ATT related which resolved with temporary discontinuation of therapy. No increased incidence of rash or neutropenia was seen in Nevirapine $400 \mathrm{mg}$ OD group. No serious neuropsychiatric abnormalities occurred with efavirenz, none of the patients developed tenofovir-induced nephrotoxicity.

After one year of treatment, we compared the treatment outcome among the patients from different groups. Composite unfavorable outcomes were comparable between the Nevirapine $400 \mathrm{mg}$ OD and Efavirenz group. We found better outcome with Nevirapine $400 \mathrm{mg}$ 
Citation: Sinha S, Jain S, Gupta K, Hussain N, Ranjan S, et al. (2017) Once Daily Dose of Nevirapine (400 mg) Versus Twice-Daily Dose (200 mg) of Nevirapine-Based Highly Active Antiretroviral Therapy Regimens in Antiretroviral Naïve Patients with HIV and Tuberculosis Infection in India. J AIDS Clin Res 8: 689. doi: 10.4172/2155-6113.1000689

Page 6 of 7

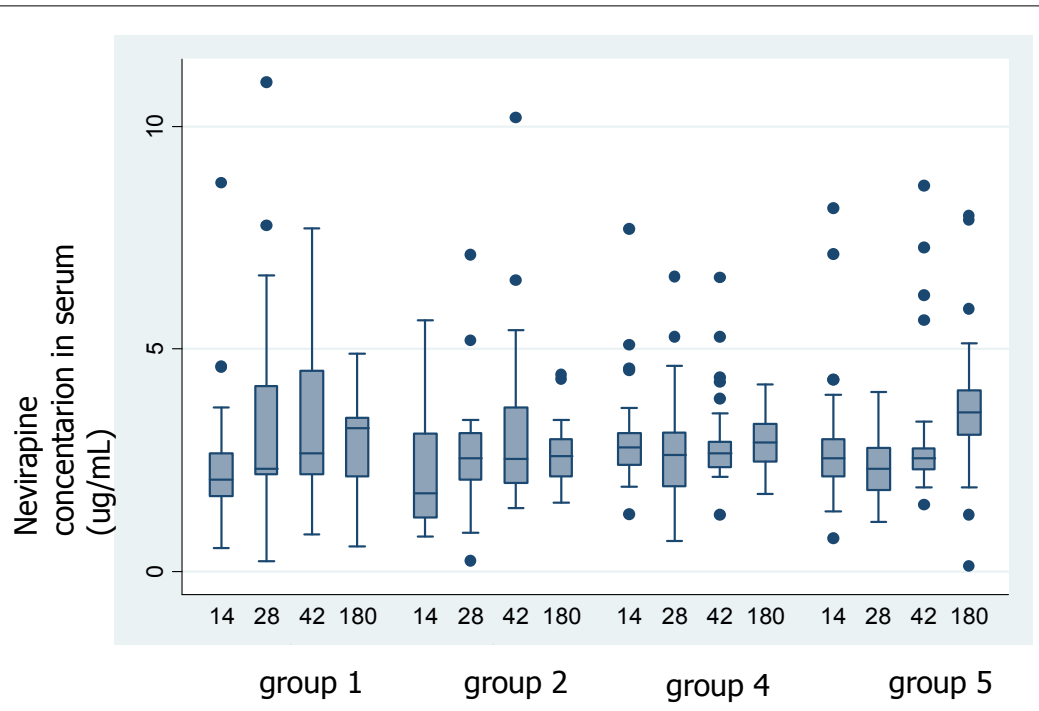

Group 1: Nevirapine 400mg OD with zidovudine and lamivudine, Group 2: Nevirapine 200 mg BD Group 4: Nevirapine 400mg OD with Tenofovir, Group 5: Nevirapine $400 \mathrm{mg}$ OD without ATT

Figure 4: Box plot showing Nevirapine values for study groups at different time point.

\begin{tabular}{|c|c|c|c|}
\hline \multicolumn{2}{|l|}{ Standards (S) } & $\begin{array}{c}\text { Test (T) } \\
\text { (NVP } 400 \text { mg OD) }\end{array}$ & $\begin{array}{c}\text { Percent T-S } \\
(95 \% \text { Confidence Interval })\end{array}$ \\
\hline NVP 200 mg BD & $20 \%$ & \multirow{3}{*}{$6.66 \%$} & $\begin{array}{c}13.3 \% \\
(-27 \text { to } 0.8)\end{array}$ \\
\hline Efavirenz & $6.66 \%$ & & $\begin{array}{c}0.00 \% \\
(-10.5 \text { to } 10.5)\end{array}$ \\
\hline Tenofovir & $6.4 \%$ & & $\begin{array}{c}0.21 \% \\
(-10.2 \text { to } 10.6)\end{array}$ \\
\hline
\end{tabular}

Table 3A: Non-inferiority of Nevirapine (NVP) $400 \mathrm{mg}$ OD to other drug based on unfavorable composite outcome from treatment response.

OD compared to Nevirapine $200 \mathrm{mg}$ BD. Based on the composite unfavorable outcome we tested if Nevirapine $400 \mathrm{mg}$ OD is noninferior or not. Table 3A shows that Nevirapine $400 \mathrm{mg}$ OD is noninferior to the other standard regimen (Efavirenz-based) for assumed non-inferiority margin (15\%).

\section{Discussion}

This open-label, randomized clinical trial demonstrated that in HIV-TB co-infected individuals receiving rifampicin- based ATT, there was no significant difference between Nevirapine $400 \mathrm{mg}$ OD based HAART regimens with zidovudine/tenofovir as an NRTI and the present preferred Efavirenz-based ART in HIV-TB co-infected ART naïve patients. These regimens are comparable with respect to clinical response, virological response, immunological response, side effect profile and mortality. Multiple observational and randomized trials have compared the clinical efficacy and toxicity profile of Nevirapine $400 \mathrm{mg}$ OD with the conventional Nevirapine $200 \mathrm{mg}$ BD and efavirenz $600 \mathrm{mg}$ OD. Very few trials have directly compared Nevirapine 400 $\mathrm{mg}$ OD and efavirenz which categorically establish the superiority of the efavirenz regimen [9]. Comparisons have mostly been between Nevirapine $200 \mathrm{mg}$ BD and efavirenz [5,6,13] and Nevirapine 200 mg BD and Nevirapine $400 \mathrm{mg}$ OD $[8,14]$ based regimens. In the first comparison although results are conflicting but many studies clearly establish the non-inferiority of Nevirapine $200 \mathrm{mg} \mathrm{BD}$ and its applicability in resource-limited settings and intolerance to efavirenz. Regarding the comparison of Nevirapine $200 \mathrm{mg}$ BD and Nevirapine $400 \mathrm{mg}$ OD; again although results are conflicting but many trials have depicted non-inferiority of Nevirapine $400 \mathrm{mg}$ OD regimen $[15,16]$. Most of these trials, however, were in an HIV-infected cohort without concomitant TB infection. Our data suggests that Nevirapine $400 \mathrm{mg}$ OD group had better treatment outcome as compared to Nevirapine 200 mg 1 BD group. Although baseline CD4 were higher in group 1 (273.3 \pm 175 cells/ul) among the randomly selected individual's; increase in CD 4 counts after 24 weeks ( $390.3 \pm 173.5$ cells/ul) and 96 weeks (456 \pm 179 cells/ul) were higher among group 1 and the overall unfavorable outcome is better in group 1 as presented in Table 3B.

We suggest that Nevirapine $400 \mathrm{mg}$ OD based ART is a reasonable alternative to the widely recommended efavirenz-based therapy in HIV-TB co-infected cohort. There have been lingering concerns about the subtherapeutic Nevirapine concentrations when co-administered with rifampicin as a part of ATT. In our study, the trough Nevirapine concentrations were slightly lower as compared to previous studies $[17,18]$. In Nevirapine $400 \mathrm{mg}$ OD regimens the mean trough Nevirapine concentrations were around $2.3 \mu \mathrm{g} / \mathrm{ml}$. However, the Nevirapine concentrations in Nevirapine $400 \mathrm{mg}$ OD groups with concomitant ATT were comparable and statistically insignificant to the control group (Nevirapine $400 \mathrm{mg}$ OD without concomitant ATT). The clinical, immunological and virological outcomes were comparable despite subtherapeutic Nevirapine trough concentrations.

Some previous studies have expressed concerns regarding higher

\begin{tabular}{|l|c|c|c|c|c|}
\hline Outcome & $\begin{array}{c}\text { Group 1 } \\
(\mathbf{n = 3 0 )}\end{array}$ & $\begin{array}{c}\text { Group 2 } \\
(\mathbf{n = 3 0 )}\end{array}$ & $\begin{array}{c}\text { Group 3 } \\
(\mathbf{n = 3 1 )}\end{array}$ & $\begin{array}{c}\text { Group 4 } \\
(\mathbf{n = 3 0 )}\end{array}$ & $\begin{array}{c}\text { Group 5 } \\
(\mathbf{n = 3 0 )}\end{array}$ \\
\hline Successfully treated & 26 & 22 & 27 & 26 & 24 \\
\hline Lost to follow up & 2 & 5 & 2 & 4 & 4 \\
\hline Mortality & 2 & 3 & 2 & 0 & 2 \\
\hline ART failure & 0 & 3 & 0 & 3 & 0 \\
\hline Clinical failure & 0 & 2 & 0 & 0 & 0 \\
\hline Immunological failure & 0 & 0 & 0 & 2 & 0 \\
\hline Virological failure & 0 & 1 & 0 & 3 & 0 \\
\hline Composite unfavorable outcome & $2 / 30$ & $6 / 30$ & $2 / 31$ & $3 / 30$ & $2 / 30$ \\
\hline
\end{tabular}

Table 3B: Patients outcomes in different study groups at 48 weeks. 
Citation: Sinha S, Jain S, Gupta K, Hussain N, Ranjan S, et al. (2017) Once Daily Dose of Nevirapine (400 mg) Versus Twice-Daily Dose (200 mg) of Nevirapine-Based Highly Active Antiretroviral Therapy Regimens in Antiretroviral Naïve Patients with HIV and Tuberculosis Infection in India. J AIDS Clin Res 8: 689. doi: 10.4172/2155-6113.1000689

Page 7 of 7

rates of skin reactions, hepatotoxicity and other adverse reactions in Nevirapine-based ART in HIV-TB co-infection [8]. However, our previous study [6] along with many others [15,16,18] suggest that Nevirapine-based ART in HIV-TB co-infection does not lead to increase adverse events or discontinuation rates. A total of seven patients had drug-induced hepatotoxicity (none in Nevirapine $400 \mathrm{mg}$ OD based regimens, four in Nevirapine $200 \mathrm{mg} \mathrm{BD}$ and three in efavirenz groups).

This was a randomized control study while most of other studies comparing the efficacy of Nevirapine and efavirenz in HIV-TB patients are observational studies. Our study is first of its kind comparing two different NRTI-based Nevirapine $400 \mathrm{mg}$ OD regime and efavirenzregimen in an HIV-TB co-infected cohort.

There are albeit limitations to our study. A significantly higher CD4 count was seen in group 1 which may suggest that these patients were having better immunity and/or early infection. We did not do genotyping in patients with virological failure. We analyzed data on an intention to treat principle but per protocol analysis should also be done to prove non-inferiority. The sample size was small and the follow-up period was 48 weeks only. All the patients were on thrice weekly therapy, therefore, with the advent of daily ATT, it remains to be seen how drug interactions will govern clinical outcome, especially with Nevirapine-based regimens.

\section{Conclusion}

In conclusion, the efficacy and safety of Nevirapine $400 \mathrm{mg}$ OD seem comparable to the efavirenz-based ART in TB-HIV coinfected patients who are ART naïve. Due to lower cost, easy availability; Nevirapine $400 \mathrm{mg}$ OD can be easily combined with tenofovir and lamivudine as a single daily tablet which can provide a more economical alternative with similar efficacy and safety profile to the efavirenz-based regimen in these patients. Further large multi-centric study with bigger sample size will be required to confirm these findings.

\section{Acknowledgement}

I take this opportunity to thank the entire AIIMS ART Clinic, staff, DOTS Clinic staff and NACO research project staff. Without their help, the completion of the study would not have been possible. I will especially like to express my sincere thanks to Mrs. Anita, MSW and Miss Pooja Kasana, whose hard work and dedication were the keys to the success of the study. I will like to express my sincere thanks, Dr. Manish Nivsarkar, Director, B. V. Patel PERD Centre, Ahmedabad who provided Nevirapine $400 \mathrm{mg}$ tablets for this study. I will like to express my thanks to National AIDS Control Organization, Ministry of Health and Family Welfare, Government of India for funding this project.

\section{References}

1. 2014 progress report on the Global Plan (2014)| UNAIDS

2. Global tuberculosis report 2015 (2015) World Health Organization.

3. WHO (2016) Antiretroviral therapy for HIV infection in adults and adolescents.

4. Antiretroviral therapy guidelines for HIV-infected adults and adolescents (2013) National AIDS Control Organisation; New Delhi.

5. Bonnet M, Bhatt N, Baudin E, Silva C, Michon C, et al. (2013) Nevirapine versus efavirenz for patients co-infected with HIV and tuberculosis: A randomised noninferiority trial. Lancet Infect Dis 13: 303-312.
6. Sinha S, Raghunandan $\mathrm{P}$ Chandrashekhar $\mathrm{R}$, Sharma S, Kumar $\mathrm{S}$, et al. (2013) Nevirapine versus efavirenz-based antiretroviral therapy regimens in antiretroviral-naive patients with HIV and tuberculosis infections in India: A pilot study. BMC Infectious Diseases 13

7. Calmy A, Vallier N, Nguyen A, Lange JM, Battegay M, et al. (2017) Safety and efficacy of once-daily nevirapine dosing: A multicohort study. Antivir Ther 14: 931-938.

8. van Leth F, Phanuphak P, Ruxrungtham K, Baraldi E, Miller S, et al. (2004) Comparison of first-line antiretroviral therapy with regimens including nevirapine, efavirenz or both drugs, plus stavudine and lamivudine: A randomised openlabel trial, the 2NN Study. Lancet 363: 1253-1263.

9. Swaminathan S, Padmapriyadarsini C, Venkatesan P, Narendran G, Ramesh Kumar S, et al. (2011) Efficacy and safety of once-daily nevirapine- or efavirenzbased antiretroviral therapy in HIV-associated tuberculosis: A randomized clinical trial. Clin Infect Dis 53: 716-724.

10. Antiretroviral therapy guidelines for HIV-infected adults and adolescents including post-exposure prophylaxis (2007) National AIDS Control Organisation; New Delhi.

11. Sinha S, Dhooria S, Kumar S, Shah N, Velpandian T, et al. (2017) The antiretroviral efficacy of highly active antiretroviral therapy and plasma nevirapine concentrations in HIV-TB co-infected Indian patients receiving rifampicin based antituberculosis treatment. AIDS Res Ther 8: 41

12. Antiretroviral therapy for HIV infection in adults and adolescents: Recommendations for a public health approach (2006) World Health Organization.

13. Shipton LK, Wester CW, Stock S, Ndwapi N, Gaolathe T, et al. (2017) Safety and efficacy of nevirapine- and efavirenz-based antiretroviral treatment in adults treated for TB-HIV co-infection in Botswana. Int J Tuberc Lung Dis 13 360-366.

14. Brinson C Bogner JR, Nelson M, Podzamczer D, Quinson AM, et al. (2013) Verxve 144-week results: Nevirapine extended release (NVP XR) Qd versus NVP immediate release (IR) bid with FTC/TDF in treatment-naive HIV-1 Patients. J AIDS Clin Res 4: 233.

15. Villar Garcia J, Vallecillo G, Gonzalez-Mena A, Sorli Redo L, Lopez Colomes $\mathrm{JL}$, et al. (2009) Non-nucleoside analogue use with rifampicin in HIV-infected patients with tuberculosis. HIV Med 10: 39-40.

16. Alexander C, Asselin J, Ting L, Montaner J, Hogg R, et al. (2003) Antiretroviral concentrations in untimed plasma samples predict therapy outcome in a population with advanced disease. J Infect Dis 188: 541-548

17. Veldkamp AI, Weverling GJ, Lange JM, Montaner JS, Reiss P, et al. (2001) High exposure to Nevirapine in plasma is associated with an improved virological response in HIV-1-infected individuals. AIDS 15: 1089-1095.

18. Kamateeka M, Barlow-Mosha L, Mubiru M, Lutajumwa M, Mudiope $P$ et al. (2017) Immunologic and virologic responses to nevirapine based antiretroviral therapy (ART) among HIV-tuberculosis co-infected Ugandan children on rifampicin based anti-tubercular treatment. Openventio Publishers 2. 